\title{
Jurisdiction Ratione Temporis in Successive International Investment Agreements: What Can Chinese Investors Learn from the Ping An Case?
}

Chunlei Zhao*

China's foreign investment has been growing rapidly since 1990s. In this course, the first investor-state arbitration case raised by a mainland Chinese investor, Ping Anv. Belgium, drew attention to an important issue - jurisdiction ratione temporis in successive international investment agreements. It is controversial in theory and practice as to whether the basic principle of non-retroactivity should apply to the dispute settlement clause in a successive agreement. This is especially true when tribunals are interpreting different kinds of jurisdictional clauses. This paper will take the Ping An Case as an opportunity to thoroughly analyze the issue of temporal jurisdiction in successive international investment agreements. Based on such analysis, this paper will also do reflection on relevant articles in China's existing investment agreements, providing suggestions to China regarding the issue of jurisdiction ratione temporis, in an effort to make arbitration more certain and avoid possible dismissal, as occurred in the Ping An Case.

Keywords: Dispute Settlement Clause, International Investment Agreements, Investor-State Arbitration, Jurisdiction Ratione Temporis, Non-Retroactivity

* Ph.D. candidate in Law at Maastricht University; Attorney-at-Law (China Bar). LL.B.(CUPL), LL.M.(CUPL / Hamburg). ORCID: http://orcid.org/0000-0001-6175-9991. The author may be contacted at: chunlei_zhao@yahoo.com / Address: Maastricht University Faculty of Law, P.O. Box 616, 6200 MD, The Netherlands. 


\section{INTRODUCTION}

China's foreign investment has been growing rapidly since 1990s. Within a short period of time, its status changed from a recipient of foreign direct investment ("FDI") to that of a significant player in both the inflow and outflow of FDI. China's achievement in attracting foreign investment is largely due to the Chinese government's reformation of its legal framework. ${ }^{2}$ An indispensable part of this legal framework is international investment agreements ("IIAs"). Since the first IIA with Sweden in 1982, China has signed more than 150 Agreements, including bilateral investment treaties ("BITs") and BIT-type chapters in free trade agreements. $^{3}$

In spite of progress in IIAs, China did not correspond with active participation in investor-state arbitration, which is a special dispute settlement mechanism. The caseload of investor-state arbitration worldwide has exploded since $2000 .{ }^{4}$ However, so far, there have only been nine such cases involving Chinese investors (including mainland, Hong Kong, Macao and Taiwan) for which information is available to the public. ${ }^{5}$ Among these nine cases, as of October 22, 2016, two cases have been settled; five cases are pending (as of August 16, 2016); and, only in two cases, the tribunals have reached arbitral awards. ${ }^{6}$ One case was raised by a Hong Kong investor in 2007, ${ }^{7}$ while the other, "Ping An Life Insurance Company of China, Limited and Ping An Insurance (Group) Company of China, Limited v. Kingdom of Belgium" (hereinafter Ping An), was brought by an investor from mainland China in 2012. As the first investor-state arbitration case filed by an investor from mainland China, Ping An draws great attention from both academics and practitioners.

In April 2015, Ping An concluded with the tribunal's dismissal on jurisdictional grounds. In particular, this case highlighted the significant issue of jurisdiction ratione temporis in successive IIAs. The investor thought Ping An was subject to investor-state arbitration, but just found that (upon the tribunal's dismissal) it could only be filed under Belgian jurisdiction. This question is highly topical to China given its active attitude to conclude more IIAs in coming years and designing the different dispute settlement mechanisms in different generations of China's IIAs.

The primary purpose of this research is to analyze the issue of temporal jurisdiction in successive international investment agreements, and to provide 
suggestions to China in an effort to make investment arbitration more certain and avoid possible dismissal. This paper is composed of six parts including a short Introduction and Conclusion. Part two will introduces the basic information of Ping An. Part three will explore its key issue - jurisdiction ratione temporis or temporal jurisdiction - from both a theoretical and a practical perspective. Part four will turn back to Ping An to discuss Ping An's arguments and the tribunal's decision. Part five will provide some suggestions for China regarding the issue of jurisdiction ratione temporis in investor-state arbitration. ${ }^{8}$

\section{The Ping An Case and the Jurisdiction RATIONE TEMPORIS}

\section{A. Overview}

Ping An is affiliated with two BITs between China and the Belgium-Luxembourg Economic Union. The first one came into force in 1986 (hereinafter 1986 BIT), which was later substituted and replaced by a successive BIT coming into effect in 2009 (hereinafter 2009 BIT). The Chinese investor, Ping An made its investment in a Belgian-Dutch company between 2007 and 2008. Before the 2009 BIT came into force, the Belgium government undertook a series of policies that Ping An, the Claimant, alleged were a breach of treaty obligations. ${ }^{9}$ Before initiating the arbitration process, the Claimant sent three letters to Belgian authorities: the first one (October 14, 2008) expressed Ping An's dissatisfaction about Belgium's performance; the second one (October 14, 2009) stated that the former letter constituted a notice of dispute under the 1986 BIT; the last one (July 3, 2012) notified the Belgian authorities that the second letter was a notice of dispute under the 2009 BIT.

The legal problem originated in the differences between the dispute settlement mechanisms provided by the 1986 BIT and the 2009 BIT. Specifically, under the 1986 BIT, investor-state arbitration is only available to "a dispute which arises from an amount of compensation for expropriation, nationalization or other similar measures," ${ }^{10}$ while, under the 2009 BIT, any legal dispute can be referred by an investor to the International Center for the Settlement of Investment Disputes ("ICSID"). ${ }^{11}$ Compared to the 1986 BIT, the subject matter that can be referred to 
an investor-state arbitration are broader under the 2009 BIT. This to some extent indicates why Ping An endeavored to bring a claim under the 2009 BIT, i.e., the nature of its claim was not suitable for international arbitration under the 1986 BIT.

The key question in Ping An was whether the enhanced investor-state arbitration provided in the 2009 BIT was available to the instant dispute, as agreed by both parties, that the dispute arose before the 2009 BIT's entry into force. Article 10.2 of the 2009 BIT, which is entitled 'Transition,' states:

\begin{abstract}
the present Agreement shall apply to all investments made by investors of either Contracting Party in the territory of the other Contracting Party, whether made before or after the entry into force of this Agreement, but shall not apply to any dispute or any claim concerning an investment which was already under judicial or arbitral process before its entry into force. Such disputes and claims shall continue to be settled according to the provisions of the Agreement of 1984 mentioned in paragraph 1 of this Article [Emphasis added].
\end{abstract}

As the dispute before the tribunal had not been "under judicial or arbitral process," the parties' arguments mainly focused on whether the instant dispute was also excluded by this provision.

\title{
B. The Tribunal's Decision
}

Regarding the issue of temporal jurisdiction, the tribunal first identified that there was a lacuna under Article 10.2 of the 2009 BIT concerning the jurisdiction. The tribunal stated: "The 2009 BIT does not expressly deal with the fate of disputes arising before December 1, 2009 which had been notified under the 1986 BIT but were not then the subject of judicial or arbitral process." ${ }^{12}$ In other words, Article 10.2 did not tell the tribunal whether it had jurisdiction over the instant case or not.

After identifying the issue as one of treaty interpretation, the tribunal addressed the question of the different applicable methods of interpretation in accordance with the Vienna Convention on the Law of Treaties ("VCLT"). The tribunal delivered the six following reasons as to why the 2009 BIT did not cover the dispute. First, Article 8.1 of the 2009 BIT stipulated that: "When a legal dispute arises between an investor of one Contracting Party and the other Contracting Party, either party to the dispute shall notify the other party to the dispute in 
writing." arises or has arisen..., either party to the dispute shall notify, or shall have notified..." [Emphasis added] Therefore, the plain language of this article appeared "to exclude on its face the expansive interpretation for which the Claimants have advocated." and purpose" of the treaty, could not assist on the present issue. Third, although the 2009 BIT applied to all investments, it did not answer the question of the effect on a dispute arising before its entry into force. Fourth, Article 10.2 itself could not support the inference that the 2009 BIT governed the pre-2009 BIT disputes which were notified under the 1986 BIT but not under judicial or arbitral process. Fifth, although the 2009 BIT "substitutes and replaces" the 1986 BIT, it did not imply that the instant dispute would survive under the 2009 BIT. Sixth, "[A] most important indicator" against expansive interpretation of the jurisdictional clause is that it would open the door for claims already notified under the 1986 BIT to a 'significantly broader' dispute settlement mechanism under the $2009 \mathrm{BIT}^{15}$ In the end, the tribunal came to the conclusion that Belgium's objection to the jurisdiction ratione temporis prevailed, thus Ping An's claim was dismissed for lack of temporal jurisdiction. ${ }^{16}$

\section{Theoretical Foundation OF JuRisdiction RATIONE TEMPORIS}

\section{A. The Principle of Non-Retroactivity}

\section{General Application in Treaties}

Unless otherwise agreed, a treaty cannot have any effect on actions carried out before its existence. ${ }^{17}$ This is usually called the principle of non-retroactivity or the rule against retroactivity, which means, generally, a treaty obligation cannot be breached through an act undertaken before the treaty's entry into force. ${ }^{18}$

As has been confirmed by the customary international law rules, Article 28 of the VCLT states:

Unless a different intention appears from the treaty or is otherwise established, its provisions do not bind a party in relation to any act or fact which took place or 
any situation which ceased to exist before the date of the entry into force of the treaty with respect to that party.

The UN International Law Commission ("ILC") explained that the main function of this rule is to guide the conduct of the subjects of law in the future, since conduct can "only be discharged if the obligations exist before the subjects prepare to act." to regulate their conduct in advance. ${ }^{20}$ This is also stated in Article 13 of the ILC's Draft Articles on State Responsibility, which reads: "An act of a State does not constitute a breach of an international obligation unless the State is bound by the obligation in question at the time the act occurs. ${ }^{21}$ In addition, it has been affirmed repeatedly by international tribunals. ${ }^{22}$

In summary, the principle of non-retroactivity has been widely confirmed and its rationale can be summarized as treaties are meant to guide conduct in the future and subjects should be given notice before they are held accountable. ${ }^{23}$

\section{Application on Dispute Settlement Clauses}

Article 28 of the VCLT does not differentiate its application on provisions dealing with substantive and procedural rights. According to the rationale supporting the principle of non-retroactivity, there should be no doubt that substantive provisions do not bind parties in respect of performance which happened before the treaty's entry into force. ${ }^{24}$ However, this principle may not apply directly to dispute settlement clauses, an issue for jurisdiction.

There are different opinions on this point. Some argue that the principle of nonretroactivity should apply to all articles in an investment treaty including dispute settlement clauses. ${ }^{25}$ This means the dispute settlement mechanism provided in the treaty is only available when the acts exists after it came into effect. Others hold that a pure jurisdictional clause should be different from substantive ones regarding the application of the principle of non-retroactivity, because the former does not impose any substantive obligation. ${ }^{26}$ As a result, the dispute settlement clause under a treaty without any expressed limitation on jurisdiction ratione temporis could be available to all acts, even the ones that predate the treaty. It has been further argued that it is not "a prima facie violation of the rule against retroactivity" to allow a dispute involving obligations before the treaty entered 
into force to be submitted to a tribunal under that treaty. ${ }^{27}$ In addition, the Third Report on the Law of Treaties made an argument based on the word used in dispute settlement clauses. It states that the word 'disputes' is used in such provisions according to its natural meaning and is "apt to cover any dispute which exists between the parties after the coming into force of the treaty," irrespective of whether it relates to events that occurred before its entry into force or itself arose prior to it. $^{28}$

Different perspectives on the non-retroactivity of jurisdictional clauses constitute diverse bases for decision-making regarding jurisdiction ratione temporis in dispute settlement practice. A problem may also arise that it is uncertain which theory a tribunal might apply.

\section{Parties' Other Agreements}

As stated in Article 28 of the VCLT, the general principle should give way to a particular intention established by the parties since, as mentioned above, the tribunal's power is derived from the parties' consent. Applying this to the temporal jurisdiction issue, the fact that "a different intention appears from the treaty or is otherwise established" could be a reasonable ground for parties giving "a treaty, or some of its provisions, retroactive effects if they think fit." ${ }^{29}$

By reviewing existing IIAs that have been cited and discussed in international investment arbitration cases, we can find that parties usually include a provision expressing their specific intention regarding the jurisdiction ratione temporis in the successive IIA. However, there are different ways of designing this provision, which in turn makes the key issue as to how a tribunal would interpret such a provision.

\section{B. Methods of Treaty Interpretation}

Before examining diverse provisions concerning temporal jurisdiction in IIAs, understanding the methods of interpretation employed by courts and tribunals is necessary. The starting point for exploring basic methods of treaty interpretation is Articles 31 and 32 of the VCLT. Article 31.1 of the VCLT states that: "A treaty shall be interpreted in good faith in accordance with the ordinary meaning to be given to the terms of the treaty in their context and in the light of its object and purpose." Four elements are stressed here: "ordinary meaning of the terms," 
'context,' "object and purpose" and 'good faith. ${ }^{30}$ Specifically when interpreting treaties, parties' intention should be presumed to reflect the ordinary meaning of the terms used by them. At the same time, the context, object and purpose of the treaty should also be considered together. In addition, the principle of interpretation in good faith, flowing from the rule of pacta sunt servanda, must be followed. $^{31}$

After applying the method provided in Article 31, if the meaning of a certain provision is still "ambiguous or obscure," or the relevant result is "manifestly absurd or unreasonable," Article 32 further provides "supplementary means of interpretation, including the preparatory work of the treaty and the circumstances of its conclusion."

The methods of treaty interpretation in the VCLT have been widely adopted in international investment arbitration cases. ${ }^{32}$ Although the methods themselves seem not very complicated, it is not hard to find that in practice, by applying these methods, arbitral tribunals still reach different conclusions under similar situations.

\section{Jurisdiction Ratione Temporis in Practice}

\section{A. Main Categories of Provisions on Jurisdiction Ratione Temporis in Existing IIAs}

The provisions concerning the issue of jurisdiction ratione temporis in existing IIAs, especially those involved in existing investment arbitration cases, can be divided into five categories based on the ways they regulate temporal jurisdiction, particularly, the different key terms used in these provisions. ${ }^{33}$ As argued above, although the temporal jurisdiction of the substantive provisions and that of the dispute settlement mechanism should be differentiated, in practice, the provisions that States include therein usually do not make such a distinction. Namely, such provisions simply stipulate temporal jurisdiction of the IIAs as a whole.

\section{Expressing No Limitation}

In general, there is no explicit temporal restriction on jurisdiction in parties' IIAs. A typical example can be found in the China-Nigeria BIT signed in 2010. Article 11 of the BIT states: "This Agreement shall apply to investments, which are made prior to or after its entry into force by investors of either Contracting Party 
in accordance with the laws and regulations of the other Contracting Party in the territory of the latter."

It should be noted that if a treaty applies to investments adopted before its entry into force, it does not equal to having retroactive application to disputes or events happening before it came into effect. Moreover, when there is no express limitation on temporal jurisdiction in IIAs, the general default rule, which is the principle of non-retroactivity, can play a decisive role. In other words, such silence does not alter the application of the general principle, but in specific cases, tribunals may decide that the general principle applicable to the substantive provisions, namely non-retroactivity, does not necessarily apply to the jurisdictional provision of the dispute settlement mechanism.

\section{Excluding Disputes Arising out of Events Happening before the Treaty's Entry into Force}

Another type of clause explicitly excludes disputes arising out of acts, events, facts or situations that happened before the treaty coming into force. In the ChinaSwitzerland BIT signed in 2009, e.g., Article 2 states:

\footnotetext{
...the present Agreement shall apply to investments in the territory of one Contracting Party made in accordance with its laws and regulations by investors of the other Contracting Party, whether prior to or after the entry into force of the Agreement. It shall however not be applicable to claims or disputes arising out of events which occurred prior to its entry into force." [Emphasis added]
}

This category of IIAs exclude jurisdiction, including that of tribunals established under such IIAs, over the disputes resulting from actions or events happening before the treaty's effective date. The effect of such exclusion is similar to applying non-retroactivity to procedural clauses, which excludes the possibility of using the dispute settlement mechanism provided in the new IIA to arbitrate the acts that happened before. For this category, the decisive issue is when the event originating the dispute took place.

\section{Excluding Disputes Arising before the Treaty's Entry into Force}

Compared to the former two categories, a clause excluding disputes arising before 
the treaty's entry into force is a more frequently used type of exclusion, which can be seen in many existing IIAs. Article 11.1 of the China-Russia BIT of 2009 stipulates:

This Agreement shall apply to all investments made by investors of one of the Contracting Parties in the territory of the other Contracting Party beginning from January 1st 1985, but shall not apply to the disputes that arose before the entry into force of this Agreement. [Emphasis added]

If there is such a provision in the relevant IIA, it is significant to identify when the dispute itself arose. As long as the dispute had been raised before the IIA's entry into effect, it should not be covered by the IIA. Thus, the dispute settlement mechanism under the IIA is not available.

Such provisions cause 'uncertainty' concerning the jurisdiction over a special kind of dispute, i.e., the dispute raised after the new IIA came into force but over acts or events happening before. Such disputes literally do not belong to the explicit exclusion stipulated in this category of provision, since the disputes were raised after the IIA's entry into effect. However, these claimed acts are excluded from the governing effect of the substantive provisions in the new IIA by the principle of non-retroactivity. Thus, the question is whether the tribunal established under the new IIA has the jurisdiction over the instant dispute which needs to be decided substantively based on the former IIA or other legal documents. ${ }^{34}$ From the author's perspective, this is one of the places where the default rule, the temporal jurisdiction principle of dispute settlement clauses, would play a decisive role. As introduced above, scholars have different views on this point. ${ }^{35}$

In some IIAs, the word is not 'dispute,' but 'difference.' Some tribunals interpreted these two terms differently by arguing that 'difference' has a lower threshold than 'dispute, ${ }^{, 36}$ while others decided that 'difference' does not have a different legal effect from 'dispute. ${ }^{37}$

\section{Excluding Claims Arising before the Treaty's Entry into Force}

Some IIAs limit the temporal jurisdiction to disputes that did not entered into any arbitral or judicial procedures. Take the provision in the China-Netherlands BIT of 2001 as an example. Article 13.2 of this treaty states: 
The present Agreement shall apply to all investments made by investors of either Contracting Party in the territory of the other Contracting Party, whether made before or after the entry into force of this Agreement, but shall not apply to any dispute or any claim concerning an investment which was already under judicial or arbitral process before its entry into force. Such disputes and claims shall continue to be settled according to the provisions of the Agreement of 1985 mentioned in paragraph 1 of this Article. [Emphasis added]

A debated provision in Ping An, Article 10.2 of the 2009 BIT between China and Belgium and Luxembourg Economic Union is also an example of this kind of clause.

Such an exclusion aims at avoiding forum shopping and excluding the possibility of contradictory decisions. Since entering into a formal dispute settlement procedure usually comes after the dispute's origin, arbitration or litigation happens after the 'event' and the 'dispute.' Thus, such an exclusion is much more restrictive than the former categories.

This kind of provision also creates a platform for applying the general principle of non-retroactivity as a default rule. Especially, there is room for explanation regarding whether the tribunal has jurisdiction over acts happening or the disputes that were raised before the IIA's entry into force, but which had not been submitted to any judicial or arbitral process.

\section{Excluding Disputes based on Subject Matters}

Within this categories, regulation of the access to the dispute settlement mechanism under the IIAs is directly provided, rather than stating the temporal jurisdiction of the whole IIAs generally. Such a provision usually grants jurisdiction over disputes concerning the interpretation of the present agreement, through which the temporal jurisdiction of the dispute settlement mechanism is correspondingly limited. ${ }^{38}$ Article 1116.1 of the North American Free Trade Agreement ("NAFTA") states:

an investor of a Party may submit to arbitration under this Section a claim that another Party has breached an obligation under: (a) Section A or Article 1503(2) (State Enterprise), or (b) Article 1502(3)(a) (Monopolies and State Enterprises) where the monopoly has acted in a manner inconsistent with the Party's 
obligations under Section A...” [Emphasis added]

Through explicit expression, this kind of provision builds a connection between the jurisdiction of substantive clauses and that of the dispute settlement mechanism. In particular, it establishes the tribunal's jurisdiction on the substantive obligations under the new IIAs. Since States bear these obligations only after the IIA's entry into force, the temporal jurisdiction of the dispute settlement mechanism is restricted to acts that happened after the IIA coming into effect.

This kind of exclusion keeps all disputes that do not originate from the present IIA, out of the reach of the dispute settlement mechanism established therein. Therefore, it eliminates the possibility of using the dispute settlement clause in the new IIA, while applying the substantive obligations listed in the former IIA or other legal documents.

\section{Summarizing the Main Categories of Provisions on Jurisdiction Ratione Temporis in Existing IIAs}

As can be seen from the above analyses, there are different categories of jurisdictional provisions available in existing IIAs. Sometimes the difference is as small as a word, such as 'dispute' rather than 'difference.' However, these differences can lead to different outcomes regarding whether a tribunal retains jurisdiction and hears the case, or dismisses it much to the disadvantage of the claimant, who is always the investor seeking some type of protection. To summarize, different kinds of provisions on temporal jurisdictions in IIAs show parties' diverse intentions, which would simultaneously cause complexity regarding the interpretation of such provisions.

\section{B. Jurisdiction Ratione Temporis in Existing Investor-State Arbitration Cases ${ }^{39}$}

Investment tribunals have mentioned that they bear the duty of contributing to the harmonious development of investment law, in order to meet the legitimate expectations of host States and investors and enhance the legal certainty and the rule of law in this area. ${ }^{40}$ To reach this goal, it is good to refer to former cases. Dolzer and Schreuer said: "Drawing on the experience of past decision-makers could secure the necessary uniformity, stability of the law and the predictability and the authority of decisions." 41 Although, in international investment arbitration, 
tribunals are not required to refer to former cases, "[d]iscussion of previous cases and of the interpretations adopted in them is a regular feature in almost every decision.. ${ }^{42}$ Usually, tribunals do compare the situation in the present case with former ones; if the situation is similar and the present tribunal accepts the logic and decision made in former cases, then the same decision would be adopted. If the tribunal, however, finds the present case can be distinguished from the earlier ones, or it is not convinced by the reasoning given in previous cases, it is free to make a different decision.

In such situations, this sub-section selects typical cases regarding the issue of jurisdiction ratione temporis, most of which happened after 2000, to ascertain how the theory has been used in recent practice. In general, to make a decision on the issue of the temporal jurisdiction, the investment arbitral tribunals would take following series of steps: (1) It will identify the provision on the issue of jurisdiction ratione temporis contained in the involved IIA; (2) if there is any expressed limitation, it will interpret the provision, especially the key terms, such as 'dispute' or 'event'; and apply such an term to the facts in the case; (3) if there is no express limitation, or the instant dispute does not fall under the expressed limitation, it will apply the preferred general principle of temporal jurisdiction, namely non-retroactivity, to reach a conclusion. Since different categories of provisions concerning temporal jurisdiction in IIAs (item 1) have been introduced above, the following discussion will cover the other steps (items 2 - 3) based on that which has been decided in investment arbitral awards. ${ }^{43}$

\section{Identification of 'Dispute, ' Event' and 'Claim'}

Although IIAs refer to diverse terminologies to identify the scope of temporal jurisdiction, but the most-frequent one is 'dispute.' Other choices, such as 'act,' 'event' or 'claim,' are related to identifying the 'dispute.' In fact, what tribunals usually do first is to confirm the matter that constitutes the 'dispute.' Then, they move to identify other terms, if necessary.

\section{The Definition of 'Dispute'}

Even though the disputing parties disagree on certain events, it does not directly mean a legal dispute exists at the time. ${ }^{44}$ Then the question is: what is the technical and legal standard for when a certain dispute begins to take shape. 
IIAs usually do not provide a definition of 'dispute.' The Convention on the Settlement of Investment Disputes between States and Nationals of Other States (hereinafter ICSID Convention) does not define it, either. Most tribunals rely on the definition provided by the International Court of Justice in Mavrommatis Palestine Concessions. ${ }^{45}$ In this case, the ICJ defined a 'dispute' as "a disagreement on a point of law or fact, a conflict of legal views or of interests between two persons." 46

\section{'Dispute', 'Event' and 'Claim'}

This definition is very broad and seems to include all possible disagreements. As introduced above, besides 'dispute,' IIAs used to adopt other terms to define temporal jurisdiction like 'event' and 'claim.' What are main differences between 'dispute' and 'event' and 'claim.'?

First, regarding 'dispute' and 'event,' the tribunal in Duke Energy International Peru Investments No. 1 Ltd. v. Republic of Peru pointed out: "There is indeed a distinction between a jurisdictional objection ratione temporis based on: (i) the time at which the dispute between the parties arose; and (ii) the time at which the underlying events giving rise to the claim arose. ${ }^{, 47}$ No matter whether the IIAs use the term 'event' or 'dispute,' it is essential to have a clear standard to distinguish one from the other. However, it is not an easy task because they are interconnected with each other chronologically and substantively.

In Emilio Agustín Maffezini, the tribunal differentiated 'event' and 'dispute' by describing the process of the emergence of a dispute. The tribunal stated that there is "a natural sequence of events that leads to a dispute," which begins with "the expression of a disagreement and the statement of a difference of views" and "the conflict of legal views and interests will only be present in the latter stage." ${ }^{49}$ Thus, it is of significance as to whether the expression entails a conflict of legal views and interests. In that case, the point when the disinvestment proposals were discussed between the parties was that when the conflict of legal views and interests came to be clearly established. ${ }^{50}$ The logic of such a sequence has been followed in later investment arbitration cases, such as in Railroad Development Corporation v. Republic of Guatemala.$^{51}$

In Emilio Agustin Maffezini, the tribunal maintained: "While a dispute may have emerged, it does not necessarily have to coincide with the presentation 
of a formal claim., 52 Therefore, the distinction between 'dispute' and 'claim' is also needed. Such a differentiation is not confusing, since it should be easy to identify once a dispute has been filed with any arbitral or judicial forum. In practice, however, this issue becomes controversial where there is a "fork-inthe-road" provision, by which the choice of an investor to bring the dispute to a domestic court or international arbitration is final and excludes the other. Under such a circumstance, parties usually argue about whether the dispute before the investment arbitral tribunal is the same as that which has been decided by the domestic judicial body, which would then constitute an obstacle for the present tribunal to gain its own jurisdiction. ${ }^{53}$

In Empresas Lucchetti, S.A. and Lucchetti Peru, S.A. v. Republic of Peru (hereinafter Lucchetti Case), e.g., the parties have argued about whether disputes over different decrees issued by the government of Peru should be deemed as the same dispute. The tribunal adopted the standard that "the critical element in determining the existence of one or two separate disputes is whether or not they concern the same subject matter." not the facts or considerations that gave rise to the earlier dispute continued to be central to the later dispute." ${ }^{, 55}$ Taking the facts underlying each dispute into consideration, the tribunal found unequivocally that "both disputes originated in the municipality's stated commitment to protect the environmental integrity and its repeated efforts to compel Claimants. ${ }^{, 56}$ Namely, the reasons given for the adoption of the later decree were "directly related to the considerations" ${ }^{\text {"57 }}$ that gave rise to the former dispute. Therefore, the final adoption of a decree revoking an authorization granted by a local court "merely continued the earlier dispute." The Claimant further contended that the instant dispute was a dispute under the BIT, which was different from former disputes, to support its argument of a new 'dispute. ${ }^{59}$ The tribunal denied this argument by stating that: "This is so only if and when the claim seeks the adjudication of a dispute which, ..., is not a dispute that arose prior to that treaty's entry into force. ${ }^{.60}$ As a result, the decisive date was determined to be the one when the first act happened.

In a similar case, Jan de Nul N.V. and Dredging International N.V. v. Arab Republic of Egypt, the tribunal seemingly did not follow the idea adopted in the Lucchetti Case. When a dispute that had been brought to a domestic court of Ismailia before the new IIA's entry into force, the tribunal recognized that 
the decisive issue was "whether the dispute before this Tribunal is different from the dispute decided by the Court of Ismaillia." ${ }^{, 61}$ After examining relevant facts, the tribunal found that the subject matter of the two proceedings were different: the former one before the Egyptian court was related to the contract interpretation under Egyptian law, while the current one before the international investment arbitral tribunal dealt with the alleged violation of the obligation under the investment agreement between two States. ${ }^{62}$ This tribunal recognized the effects of different applicable laws (domestic law and IIA) for different subjects (contractual disputes and treaty disputes) in different forums (domestic courts and international arbitrations) in determining the nature of dispute, which deviates from the Lucchetti Case. ${ }^{63}$ In addition, the tribunal in Jan de Nul N.V. and Dredging International N.V. v. Arab Republic of Egypt further stated that although "the domestic dispute antedated the international dispute and ultimately led towards it," eliminated all prospects that the Claimants could obtain redress from the Egyptian State." ${ }^{65}$ In the end, the tribunal concluded that the original dispute "has (re) crystallized into a new dispute when the Ismaïlia Court rendered its decision., ${ }^{, 66}$

\section{Acts with a Continuing Character and Composite Acts}

Sometimes the alleged violation of a certain IIA is not a single and instant act or event. Instead, it is an act or event with a continuing nature, ${ }^{67}$ such as a failure to pay certain amount of money due, ${ }^{68}$ or an omission of preventing a given event which occurs and extends over the entire period. ${ }^{69}$ If an act that happened before but continued after the treaty's entry into force, it will cause difficulties to determine the relevant time points, i.e., when the 'act' or 'event' happened and when the 'dispute' arose.

If the disputed act has a continuing character, it has been determined that the breach extended over "the entire period during which the act continues and remains not in conformity with the international obligation. ${ }^{, 70}$ In other words, acts continuing over a period covering the effective date of the IIA should be deemed as having happened both before and after the IIA's entry into force.

However, there is a distinction between a continuing act and an act not having a continuing character, but a continuing effect. If acts had been completed or the situation had ceased to exist before the treaty's entry into force, although the 
effects continues, it should be deemed as having occurred at the moment when the act was first performed. ${ }^{71}$ This position has been consistently adopted by such decisions as Mondev International Ltd. v. United States of America, ${ }^{72}$ SGS Société Générale de Surveillance S.A. v. Republic of the Philippine ${ }^{73}$ and Railroad Development Corporation v. Republic of Guatemala. ${ }^{74}$

Similar reasoning applies to composite acts. When there is a series of acts or omissions spreading over time which serve for the same purpose, such as a certain creeping or indirect expropriation, the point when the 'act' or 'event' happened should be the time of the completion of such acts. ${ }^{75}$ This opinion has been adopted by several cases, such as OKO Pankki v. Estonia.

Now the issue turns to the date when the relevant 'dispute' happened for a continuing or composite act, especially when the investor started to raise its objection at an early stage. In Mondev International Ltd. v. United States of America, the tribunal put forward that: "The crystallization of the dispute has been deemed as the point when the investor's alleged right was definitively rejected." Through comprehensive consideration, it finally decided that: "The subsequent failure of the United States courts to provide any remedy for that continuing situation was itself, in the circumstances, a breach of Article 1105(1), which matured only with the definitive rejection of Mondev's claims." ${ }^{, 77}$ In other words, the investor was deprived of its right by the final and decisive event of the host State, leading to the 'dispute.'

\section{The Application of the Principle of Non-retroactivity}

There is scant argument, either in theory or practice, on the application of the non-retroactivity principle to the substantive provisions in treaties. Meanwhile, regarding temporal jurisdiction of procedural clauses, there are both different opinions and approaches in theory and international practice.

Some tribunals have persisted in an equal application of non-retroactivity to all provisions. As a result, a dispute settlement clause in a successive IIA would not be available to disputes arising before the IIA's entry into force, especially when there is no express inclusion of the disputes arising before the entry into force of the parties' IIA. The tribunal in MCI Power Group LLC and New Turbine Inc. $v$ Ecuador stated: "The silence of the text of the BIT with respect to its scope in relation to disputes prior to its entry into force does not alter the effects of the 
principle of the non-retroactivity of treaties." ${ }^{, 78}$ In support of this position, some tribunals further found justification from the perspective of the distinctive nature of certain dispute settlement clauses in IIAs. "When a jurisdictional clause is attached to the substantive clauses of a treaty as a means of securing their due application," specifically, the non-retroactivity principle "may operate to limit ratione temporis the application of the jurisdictional clause." capacity as insolvency administrator of Walter Bau Ag (In Liquidation) v. The Kingdom of Thailand, e.g., the tribunal pointed out that when an article introduces the possibility of investor-state claims, it should be deemed as a substantive rather than a mere procedural provision, which justifies the application of Article 28 of the VCLT. ${ }^{80}$ It is further explained that the clear intention of the successive treaty was to provide better future protection for investors than that which had previously existed, including an easier way for an investor to seek redress through an additional investor-state dispute settlement mechanism. ${ }^{81}$ According to this theory, if continuing or composite acts do not end before the IIA's entry into effect, they will not fall under the exclusion of non-retroactivity, because the "non-retroactivity principle cannot be infringed by applying a treaty to matters that occur or exist when the treaty is in force, even if they first began at an earlier date. ${ }^{, 82}$

In other cases, however, arbitral jurisdiction was available for disputes happening before the treaty's entry into force. Some tribunals argued that jurisdiction based on an international agreement covered, as a rule, "all disputes referred to it after its establishment. ${ }^{, 83}$ Although, in theory, it seems reasonable to differentiate the application of the principle of non-retroactivity between substantive and procedural provisions, it is not usual for the investment arbitration tribunals to use the dispute settlement mechanism from one IIA and the substantive provisions from another IIA. $^{84}$

Furthermore, as noted before, many IIAs have their own provisions regulating jurisdiction ratione temporis, so the important question in such circumstances is how to apply the general principle of non-retroactivity under the diverse models for such provisions. Usually, a problem may arise where non-retroactivity is applied to the dispute settlement clause and, at the same time, there is an express prohibition on retrospective temporal operation to certain disputes in parties' IIAs. If such a provision changed the legal effect of non-retroactivity, party autonomy should be respected. However, what if the provision only includes part of the 
excluded disputes by the principle of non-retroactivity? Such provisions have been interpreted by tribunals as "states acting under an abundance of caution." Namely, since the general rule on non-retroactivity is a well-established principle, it does not need to be included expressly in a treaty in order to realize its application; if there is such an expression, it should be deemed as acting ex abundante cautela. Therefore, the final result would be the same as just applying the general principle of non-retroactivity.

\section{Reflection on the Ping An Case}

\section{Ping An's Argument}

First, according to Article 10.2 of the 2009 BIT, unless the dispute had been under a judicial or arbitral process, it should be covered by the 2009 BIT, including the dispute settlement provision. This argument did not address the principle of nonretroactivity, which had been applied to procedural clauses in earlier cases. Parties could change this principle only explicitly in their IIA. Otherwise, the disputes raised before the new IIA came into effect, like the dispute in Ping An, would probably not be subject to the dispute settlement mechanism therein. Moreover, Ping An accepted the position that the instant dispute was not covered by Article 10.2 of the 2009 BIT. $^{86}$ To some extent, this was in conflict with its strongest argument that Article 10.2 of the 2009 BIT could justify the tribunal's jurisdiction, and let the tribunal's analysis develop in a way that went against Ping An's own position. ${ }^{87}$

Second, fearing that the claims could fall into the 'black hole' created by two successive BITs, Ping An would argue that no remedy would be available regarding its loss if the tribunal decided against jurisdiction. ${ }^{88}$ However, such an argument had been addressed in earlier cases that: "The mere fact that earlier conduct has gone unremedied or unredressed when a treaty enters into force does not justify a tribunal applying the treaty retrospectively to that conduct." ${ }^{, 89}$ Thus, Ping An's argument lacked a solid enough legal foundation.

Third, Ping An could have learned from Jan de Nul N.V. and Dredging International N.V. v. Arab Republic of Egypt that if a decision from a national court of the host State could be deemed as a valid 'intervention,' the original dispute may 'recrystallize' into a new dispute. Therefore, perhaps, Ping An could have chosen to go through Belgium's national courts first, bringing a contractual 
claim under Belgian domestic law. If its rights were denied, the dispute could have 'recrystallized' into a qualified dispute for the investment arbitral tribunal. ${ }^{90}$

\section{The Tribunal's Analysis}

The award in Ping An has been described as joining "a line of investment treaty awards concerning the application of successive bilateral investment treaties," such as Jan de Nul v. Egypt, ABCI Investment v. Tunisia, and Walter Bau v. Thailand. ${ }^{91}$ Concerning parties' agreement as reflected in the IIA in Ping An, the tribunal decided that the dispute before it, which had been raised - but not under any judicial or arbitral proceeding by the time the new BIT entered into force, was something that had not been touched upon by Article 10.2 of the 2009 BIT then in force. In other words, if parties to the IIA intended to open the door to investment arbitration for the instant dispute, the tribunal reasoned that: "Express provision would have been made for it." ${ }^{, 92}$ Therefore, the tribunal found no guidance in this provision and thus needed to find other ways to determine the parties' intent.

In the beginning of such exploration, the tribunal stated that since "the application of a new dispute settlement mechanism to acts which may have been unlawful when they were committed is not in itself the retroactive application of law," it would not "employ any presumption against the retroactivity." the tribunal described the appropriate approach that should be adopted as "a narrow and purely linguistic exercise. ${ }^{94}$ By applying this method, the tribunal found inspiration mainly in Article 8.1 of the new BIT and interpreted it through a linguistic analysis by relying on three cases. ${ }^{95}$ Specifically, in these cases, the tribunals interpret 'arises' as showing parties' intent to make the IIA available for disputes happening after its entry into force. ${ }^{96}$ As a result, the tribunal in Ping An came to the conclusion that the words 'arises' and 'notify' in Article 8.1 of the 2009 BIT showed similar intention. Together with the other five justifications as introduced at the beginning of this paper, the tribunal reached the final decision against Chinese investor's application.

From the author's perspective, first, although the tribunal avoided expressing its opinion regarding the application of the principle of non-retroactivity on the jurisdictional aspects of dispute settlement clauses, the conclusion in this case can only be supported by the position that unless explicitly agreed otherwise, the dispute settlement clause in the IIA does not have retroactive effect over 
disputes that had been raised before its entry into force. In addition, the tribunal's differentiation regarding 'arise' and "arise and has arisen," one the hand, and 'notify' and 'have notified,' on the other, both in Article 10.2 of the 2009 BIT might be literal. This differentiation has been criticized as being against the 'good faith' principle and the "circumstances of its conclusion," as required by the VCLT. $^{97}$

In fact, Ping $A n$ is not the first case that caused public discussion about the reasonableness of a tribunal's approach. When interpreting treaties, some tribunals have been criticized as expressly stating that they would follow certain methods of interpretation, but not actually doing so. ${ }^{98}$ As a result, there is an uncertainty as to tribunals' interpretations even when the tribunals have said that they were using the same interpretation method. At the same time, we can see that tribunals respect, or at least refer to, the logic adopted in earlier cases. It is easy to find that, in many investment awards, tribunals state they are relying on certain investment arbitration cases. Therefore, it is reasonable to anticipate that the logic in Ping An will probably influence similar cases in the future, as well.

\section{What can China Learn from the Ping An CaSe on JuRisdiciton Ratione TEMPoris?}

Since there is no appeal mechanism available in the ICSID system and Ping An did not raise any annulment proceeding, this case has come to its end. ${ }^{99}$ Today, it is more meaningful to summarize and learn from the tribunal's approach and rethink to which China need to pay attention in the future.

So far, China has signed 15 successive IIAs. Among them, regarding the issue of jurisdiction ratione temporis, China has adopted four of the five categories mentioned earlier in this paper: (1) expressing no limitations, such as the ChinaCuba BIT (2008); (2) excluding disputes that happened before the treaty's entry into force, such as the China-Uzbekistan BIT (2011); (3) excluding disputes arising out of events that happened before the treaty's entry into force, such as China-Switzerland BIT (2010) and; (4) excluding disputes already under judicial or arbitral process before the treaty's entry into force, such as the China-Germany BIT (2005). 
By examining the provisions on jurisdiction ratione temporis in China's IIAs in detail, it is easy to find that even when the English and Chinese versions are 'equally authentic,' the same English word is used in multiple IIAs, but, in the Chinese version the terms are different. ${ }^{100}$ All of these create uncertainties and put China and Chinese parties at a risk once there is a dispute over the meaning of relevant terms.

Considering the emphasis that the tribunal in Ping An put on textual interpretation, paramount is to pay more attention to the terms used in IIAs and try to maintain consistency when it is possible. In addition, as stated above, what is actually reflected in the tribunal's decision is not always the avowed predilection for a certain method of interpretation. ${ }^{101}$ Under such a situation, an authoritative interpretation mechanism should be offered to deal with this drawback. Through such a mechanism, contracting parties could suggest guidelines for interpreting terms in their IIA, which would be important for novice panels. In fact, a consultation mechanism ${ }^{102}$ or binding interpretation mechanism ${ }^{103}$ has been provided for treaty interpretation in some IIAs. ${ }^{104}$

It is acknowledged that China has tried to introduce such a mechanism into its IIAs. E.g., a consultation mechanism was adopted in the China-Australia Free Trade Agreement entering into effect in $2015 .^{105}$ This kind of mechanism is necessary and should be insisted in China's future IIAs.

\section{Conclusion}

The issue of jurisdiction ratione temporis is important to China and Chinese investors, since more IIAs are expected to be concluded by China. The ChinaEU BIT currently being negotiated is a good example, which may replace the 26 BITs that China has concluded with 27 EU Member States. ${ }^{106}$ Furthermore, it may not only be a controversial issue under the successive IIAs, but cause problems wherever a new IIA comes into force.

Concerning the issue of temporal jurisdiction in successive IIAs, we can see that the application of the principle of non-retroactivity on substantive obligations has been widely accepted, but regarding its application on dispute settlement clauses, there is no consensus. At the same time, States could derogate from this 
general principle regarding the temporal jurisdiction of their IIAs by expressly stating otherwise. In practice, States have expressed such position by using different key terms in their IIAs that can be mainly divided into five categories. Where there are provisions in parties' IIAs regulating the temporal jurisdiction, in investor-state arbitration, tribunals first held different interpretations of the same terms used in similar provisions. In addition, tribunals would have different attitudes toward the nexus between the jurisdiction of dispute settlement clause and the application scope of substantive provisions: some tribunals separated one from the other, but others insisted on treating them in the same way, especially on the application of the principle of non-retroactivity. All of these resulted in different decisions on the temporal jurisdiction of dispute settlement clauses in successive IIAs, which contributes to the uncertainty and unpredictability of investor-state arbitration.

Although the first investment arbitration case raised by a mainland Chinese investor was rejected at the jurisdictional stage, it still provides a good opportunity for China to learn a lesson concerning jurisdiction ratione temporis in successive IIAs. It could help China revise its existing IIAs if possible, or make better proposals for IIAs in the future.

\section{REFERENCES}

1. N. Gallagher \& Wenhua Shan, Chinese Investment Treaties Policies and Practice 7-10 (2009). Chinese outbound investment increased greatly just from 2000. In 2014, the inflow and outflow of FDI in China for the first time came close to balance. For details, see PRC National Bureau of Statistics 中华人民共和国国家统计局, 2014 Statistical Bullentin of China's Outward Foreign Direct Investment 85 (Sept. 1, 2015).

2. OECD Press Release, Reforms Could Boost China's Ability to Attract Foreign Investment, July 9, 2003, available at http://www.oecd.org/industry/inv/reformscouldboostchinasabilityto attractforeigninvestment.htm (last visited on Jan. 26, 2017).

3. PRC National Bureau of Statistics 中华人民共和国国家统计局, The Series Report of the Economic and Social Development Achievement from the 16th Congress to the 18th Congress-4 从十六大到十八大经济社会发展成就系列报告之四, Aug. 21, 2012, available at http://www.gov.cn/gzdt/2012-08/21/content_2207781.htm (last visited on Jan. 26, 2017). See also GALLAGHER \& SHAN, supra note 1 , at 32 .

4. ICSID, The ICSID Caseload-Statistics (Issue 2016-1) 7 (2016), available at https://icsid. 
worldbank.org/en/Documents/resources/ICSID\%20Web\%20Stats\%202016-1\%20(English) \%20final.pdf (last visited on Jan. 26, 2017).

5. The statistic here is based on the information published by the ICSID's and italaw's websites, which may have not counted in all the existing investment arbitration cases involving China or Chinese investors.

6. However, these two cases were rejected at the jurisdictional stage, so that up to now, there has been actually no case involving China or Chinese investors coming to a decision on substantive issues.

7. Señor Tza Yap Shum v. The Republic of Peru, ICSID Case No. ARB/07/6, Award (July 7, 2011), available at http://www.italaw.com/sites/default/files/case-documents/ita0881.pdf (last visited on Jan. 26, 2017).

8. According to the bases, there are two kinds of investor-state arbitration: treaty-based arbitration and contract-based arbitration. The discussion in this paper only covers the former.

9. Ping An Life Insurance Company of China, Limited and Ping An Insurance (Group) Company of China, Limited v. Kingdom of Belgium (hereinafter Ping An case), ICSID Case No. ARB/12/29, Award, ๆ 183 (Apr. 30, 2015), available at http://www.italaw.com/sites/ default/files/case-documents/italaw4285.pdf (last visited on Jan. 26, 2017).

10. Agreement between the Government of the People's Republic of China and the BelgianLuxembourg Economic Union on the Reciprocal Promotion and Protection of Investments (1986), art. 10.3. For other kinds of disputes, if amicable settlement does not work, they "shall be subject to jurisdiction of the State where the investment is located." See id. art. 10.1 \& 10.2 .

11. Agreement between the Government of the People's Republic of China and the BelgiumLuxemburg Economic Union on the Reciprocal Promotion and Protection of Investments (2009), art. 8.

12. Supra note 9 , at 9205.

13. Supra note 11 , art. 8.1 .

14. Supra note 9 , at $\uparrow 224$.

15. Id. ๆๆ 223-231.

16. Id. $₫ 240$.

17. VCLT art. 28.

18. F. Dopagne, Article 28: Non-retroactivity of treaties, in VIENNA CONVENTION ON THE LAW OF Treaties: A Commentary 718-28 (O. Corten \& P. Klein eds., 2011).

19. See Report of the International Law Commission on the work of its twenty-eighth session (May 3-July 23 of 1976), [1976] 2:1 Y.B. Int'1 L. Comm'n 90, U.N. Doc. A/CN.4/SER. A/1976/Add.1, available at http://legal.un.org/ilc/publications/yearbooks/english/ilc_1976_ v2_p1.pdf (last visited on Jan. 26, 2017).

20. Id.

21. See Responsibility of States for Internationally Wrongful Acts 2001, in [2001] 2 Y.B. Int'1 
L. Comm'n, U.N. Doc. A/56/83 (2001), art. 13, available at http://legal.un.org/ilc/texts/ instruments/english/draft_articles/9_6_2001.pdf (last visited on Jan. 26, 2017).

22. This principle was initially invoked by human rights and other adjudicatory bodies, and then got confirmation from investment arbitral tribunals later. See, e.g., Mondev International Ltd. v. United States of America, ICSID Case No. ARB(AF)/99/2, Award, ๆ 68 (Oct. 11, 2002), available at http://www.italaw.com/sites/default/files/case-documents/ita1076.pdf (last visited on Jan. 26, 2017).

23. S. Blanchard, State Consent, Temporal Jurisdiction, and the Importation of Continuing Circumstances Analysis into International Investment Arbitration, 10 Wash. U. GLOBAL Stud. L. Rev. 428 (2011).

24. Supra note 19.

25. Qiang Ren, Ratione Temporis and Retroactivity of International Investment TreatiesExamining Tribunals'Jurisdictions by Disputes, Breaches and Arbitral/Judicial Procedure 投资仲裁实践对国际投资协定时间效力的认定-争端、争端诱因和争端程序在国际投资仲裁管辖 权界定中的应用”, 4 BEIJING ARBITRATION Q. 北京仲裁 105 (2015).

26. Supra note 23, at 429.

27. Id.

28. H. Waldock, Third Report on the Law of Treaties, in [1964] 2 Y.B. Int'l L. Comm'n 11, U.N. Doc. A/CN.4/167 \& Add. 1-3, available at http://legal.un.org/ilc/documentation/english/a cn4_167.pdf (last visited on Jan. 23, 2017).

29. Draft Articles on the Law of Treaties with commentaries (1966), in [1966] 2 Y.B. Int'1 L. Comm'n 211, available at http://legal.un.org/ilc/texts/instruments/english/ commentaries/1_1_1966.pdf (last visited on Jan. 23, 2017).

30. O. Dörr \& K. Schmalenbach (eds.), Vienna Convention on the Law of Treaties: A COMMENTARY 521-70 (2012).

31. Draft Articles on the Law of Treaties with commentaries, at 221.

32. See, e.g., Ronald S. Lauder v. The Czech Republic, UNCITRAL, Award, 1292 (Sept. 3, 2001), available at http:/www.italaw.com/sites/default/files/case-documents/ita0451. pdf; Siemens A.G. v. The Argentine Republic, ICSID Case No. ARB/02/8, Decision on Jurisdiction, 81 (Aug. 3, 2004), available at http://www.italaw.com/sites/default/files/casedocuments/ita0788.pdf; Fraport AG Frankfurt Airport Services Worldwide v. The Republic of the Philippines, ICSID Case No. ARB/03/25, Award, ๆ 337 (Aug. 16, 2007), available at http://www.italaw.com/sites/default/files/case-documents/ita0340.pdf; Austrian Airlines v. The Slovak Republic, UNCITRAL, Final Award, 9甲 101-104 (Oct. 9, 2009), available at http://www.italaw.com/sites/default/files/case-documents/ita0048_0.pdf; Alps Finance and Trade AG v. The Slovak Republic, UNCITRAL, Award, qๆ 236-237 (Mar. 5, 2011), available at http://www.italaw.com/sites/default/files/case-documents/ita0027.pdf (all last visited on Jan. 26, 2017).

33. Sadie Blanchard in his article identified 'four levels' of temporal restriction on jurisdiction, 
which did not include the forth category specified in this sub-section. See supra note 23, at 430-3.

34. In the situation where there is no former IIA, the substantive obligation may come from domestic legislation.

35. See infra ch. 3.1.2 of this article.

36. See, e.g., Helnan International Hotels A/S v. Arab Republic of Egypt, ICSID Case No. $\mathrm{ARB} / 05 / 19$, Decision of the Tribunal on Objection to Jurisdiction, ๆף 35-57 (Oct. 17, 2006), available at http://www.italaw.com/sites/default/files/case-documents/ita0398_0.pdf (last visited on Jan. 26, 2017).

37. See, e.g., Empresas Lucchetti, S.A. and Lucchetti Peru, S.A. v. The Republic of Peru, ICSID Case No. ARB/03/4, Award, ๆ甲 38-62 (Feb. 7, 2005), available at http://www.italaw.com/ sites/default/files/case-documents/ita0275.pdf (last visited on Jan. 26, 2017).

38. Supra note 23, at 432.

39. The cases cited in this sub-section are usually the ones that have been referred to by other tribunals.

40. See, e.g., Saipem S.p.A. v. The People's Republic of Bangladesh, ICSID Case No. ARB/05/ 07, Decision on Jurisdiction and Recommendation on Provisional Measures, 167 (Mar. 21,

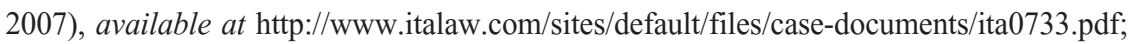
Duke Energy Electroquil Partners \& Electroquil S.A. v. Republic of Ecuador, ICSID Case No. ARB/04/19, Award, qศ 116-117 (Aug. 18, 2008), available at http://www.italaw.com/ sites/default/files/case-documents/ita0256.pdf; Saba Fakes v. Republic of Turkey, ICSID Case No. ARB/07/20, Award, II 96 (July 14, 2010), available at http://www.italaw.com/ sites/default/files/case-documents/ita0314.pdf (all last visited on Jan. 26, 2017).

41. R. Dolzer \& C. Schreuer, Principles of International Investment Law 33 (2012).

42. Id.

43. See, e.g., Emilio Agustín Maffezini v. the Kingdom of Spain, ICSID Case No. ARB/97/7, Decision of the Tribunal on Objections to Jurisdiction (Jan. 25, 2000), available at http:// www.italaw.com/sites/default/files/case-documents/ita0479.pdf (last visited on Jan. 26, 2017).

44. $I d$. $ๆ$ 91-98.

45. Id. $ๆ 94$.

46. Mavrommatis Jerusalem Concessions, Greece v United Kingdom, 1925 P.C.I.J. (ser. A) No, 5, Judgment, I 19, available at http:/www.worldcourts.com/pcij/eng/decisions/1924.08.30_ mavrommatis.htm; Case concerning East Timor (Port. v. Australia), Judgment, 1995, I.C.J. Rep. 90, 22 (June 30), available at http://www.icj-cij.org/docket/files/84/6949.pdf (all last visited on Jan. 26, 2017).

47. Duke Energy International Peru Investments No. 1 Ltd. v. Republic of Peru, ICSID Case No. ARB/03/28, Decision on Jurisdiction, 171 (Feb. 1, 2006), available at http://www. italaw.com/documents/Duke-Peru-Jurisdiction.pdf (last visited on Jan. 26, 2017). 
48. Emilio Agustín Maffezini v. the Kingdom of Spain, supra note 43, at 96.

49. Id. $₫ 97$.

50. Id. $\uparrow 98$.

51. Railroad Development Corporation v. Republic of Guatemala, ICSID Case No. ARB/07/23, Second Decision on Objections to Jurisdiction, If 29 (May 18, 2010), available at http:// www.italaw.com/sites/default/files/case-documents/ita0704.pdf (last visited on Jan. 26, 2017).

52. Emilio Agustín Maffezini v. the Kingdom of Spain, supra note 43, at 97.

53. This is a summary of various cases. A typical example, the Lucchetti case, has been introduced in the following paragraph.

54. Empresas Lucchetti, S.A. and Lucchetti Peru, S.A. v. Republic of Peru, ICSID Case No. ARB/03/4, Decision on Annulment, 950 (Sept. 5, 2007), available at http://www.italaw.com/ sites/default/files/case-documents/ita0277.pdf. As pointed out by the tribunal, this standard had been used in CMS Gas Transmission Company v. The Republic of Argentina. See CMS Gas Transmission Company v. The Republic of Argentina, ICSID Case No. ARB/01/8, Decision of the Tribunal on Objections to Jurisdiction, 109 (July 17, 2003), available at http://www.italaw.com/sites/default/files/case-documents/ita0183.pdf (all last visited on Jan. 26, 2017).

55. Empresas Lucchetti, S.A. and Lucchetti Peru, S.A. v. Republic of Peru, supra note 54, at 9 50.

56. Id. $₫ 53$.

57. Id.

58. Id.

59. $I d . \uparrow 42$.

60. Id. $₫ 59$.

61. Jan de Nul N.V. and Dredging International N.V. v. Arab Republic of Egypt, ICSID Case No. ARB/04/13, Decision on Jurisdiction, 112 (Nov. 6, 2008), available at http://www. italaw.com/sites/default/files/case-documents/ita0439.pdf (last visited on Jan. 26, 2017).

62. Id. $₫ 117$.

63. Id.

64. Id. $\uparrow 119$.

65. Id. $ๆ 118$.

66. Id. $ๆ 128$.

67. Supra note 41 , at $37-8$.

68. SGS Société Générale de Surveillance S.A. v. Republic of the Philippines, ICSID Case No. ARB/02/6, Decision of the Tribunal on Objections to Jurisdiction, 167 (Jan. 29, 2004), available at http://www.italaw.com/sites/default/files/case-documents/ita0782.pdf (last visited on Jan. 26, 2017). See also Mondev International Ltd. v. United States of America, supra note 22 , ๆๆ $58 \& 70$. 
69. Responsibility of States for Internationally Wrongful Acts, supra note 21, art. 14.3.

70. Id. art. 14.2.

71. Id. art. 14.1.

72. Mondev International Ltd. v. United States of America, supra note 22, \56.

73. SGS Société Générale de Surveillance S.A. v. Republic of the Philippines, supra note 68 , 167.

74. Railroad Development Corporation v. Republic of Guatemala, supra note 51, ๆף 123-124. See also Técnicas Medioambientales Tecmed, S.A. v. The United Mexican States, ICSID Case No. ARB (AF)/00/2, Award, ๆ 63 (May 29, 2003), available at http://www.italaw. $\mathrm{com} /$ sites/default/files/case-documents/ita0854.pdf (last visited on Jan. 26, 2017).

75. S. Alexandrov, "The "Baby Boom" of Treaty-Based Arbitrations and the Jurisdiction of ICSID Tribunals: Shareholders as "Investors" and "Jurisdiction Ratione Temporis," 4 L. \& Prac. Int'L Courts \& TRiB. 52-6 (2005). See also Responsibility of States for Internationally Wrongful Acts, supra note 21, art. 15; supra note 41, at 38.

76. Oko Pankki Oyj, VTB Bank (Deutschland) AG and Sampo Bank Plc v. The Republic of Estonia, ICSID Case No. ARB/04/6, Award, ๆๆ 184-196 \& 284 (Nov. 19, 2007), available at http://www.italaw.com/sites/default/files/case-documents/ita0583.pdf (last visited on Jan. 26, 2017).

77. Mondev International Ltd. v. United States of America, supra note 22, $₫ 66$.

78. M.C.I. Power Group L.C. and New Turbine, Inc. v. Republic of Ecuador, ICSID Case No. ARB/03/6, Award, 6.1 (July 31, 2007), available at http:/www.italaw.com/sites/default/ files/case-documents/ita0500.pdf (last visited on Jan. 26, 2017).

79. Draft Articles on the Law of Treaties with commentaries (1966), at 212.

80. Werner Schneider, acting in his capacity as insolvency administrator of Walter Bau Ag (In Liquidation) v. The Kingdom of Thailand, UNCITRAL, Award, 9.71 (July 1, 2009), available at http://www.italaw.com/sites/default/files/case-documents/ita0067.pdf (last visited on Jan. 26, 2017). Article 28 of the VCLT states: "Unless a different intention appears from the treaty or is otherwise established, its provisions do not bind a party in relation to any act or fact which took place or any situation which ceased to exist before the date of the entry into force of the treaty with respect to that party."

81. Werner Schneider, acting in his capacity as insolvency administrator of Walter Bau Ag (In Liquidation) v. The Kingdom of Thailand, $i d$.

82. Draft Articles on the Law of Treaties with commentaries (1966), at 212. Regarding the acts prior to the IIA's entry into force, on the one hand, the obligation under the new IIA will not have retroactive effects. See Société Générale In respect of DR Energy Holdings Limited and Empresa Distribuidora de Electricidad del Este, S.A. v. The Dominican Republic, LCIA Case No. UN 7927, Award on Preliminary Objections to Jurisdiciton, ๆ 9.85 (Sept. 19, 2008), available at http://www.italaw.com/sites/default/files/case-documents/ita0798. pdf (last visited on Jan. 26, 2017). On the other hand, the non-retroactivity principle does 
not exclude the consideration of prior acts that occurred after the IIA's entry into force for the "purposes of understanding the background, the causes, or scope of the violation of the BIT." See M.C.I. Power Group L.C. and New Turbine, Inc. v. Republic of Ecuador, supra note 78, \ 87.

83. See, e.g., Mavrommatis Jerusalem Concessions, Greece v United Kingdom, supra note 46, 1 90.

84. For the cases that recognized the idea of differentiating the application of the principle of non-retroactivity on substantive and procedural provisions, see, e.g., SGS Société Générale de Surveillance S.A. v. Republic of the Philippines, supra note 68, at 167; Salini Costruttori S.p.A. and Italstrade S.p.A. v. The Hashemite Kingdom of Jordan, ICSID Case No. ARB/02/13, Award, II 176 (Jan. 31, 2006), available at http://www.italaw.com/ sites/default/files/case-documents/ita0737.pdf; Ioan Micula, Viorel Micula, S.C. European Food S.A, S.C. Starmill S.R.L. and S.C. Multipack S.R.L. v. Romania, ICSID Case No. ARB/05/20, Decision on Jurisdiction and Admissibility, 157 (Sept. 24, 2008), available at http://www.italaw.com/sites/default/files/case-documents/ita0530.pdf (all last visited on Jan. 26, 2017).

85. Werner Schneider, acting in his capacity as insolvency administrator of Walter Bau Ag (In Liquidation) v. The Kingdom of Thailand, supra note 80, $₫ 9.70$.

86. Ping An case, supra note 9, at 208.

87. Id.

88. Id. at 207.

89. See, e.g., Mondev International Ltd. v. United States of America, supra note 22, at 970.

90. It is admitted that as an unavoidable drawback, this method would probably take a longer period of time to bring the case before the investment arbitral tribunal.

91. A. Ross, Belgium Prevails against Chinese Investor, Global Arbitration Rev., May 5, 2015, available at http://bankside.ongoing.co.nz/wp-content/uploads/2015/12/GAR-BelgiumPrevails.pdf (last visited on Jan. 26, 2017).

92. Ping An case, supra note 9, at 148.

93. Id. ๆ 218.

94. Id.

95. The three cases that the tribunal in Ping An relied on are: (1) ABCI Investments N.V. v. Republic of Tunisia, ICSID Case No. ARB/04/12, Decision on Jurisdiction (Feb. 18, 2011), available at http://www.italaw.com/sites/default/files/case-documents/italaw1346. pdf $<$ available only in French>; (2) Salini Costruttori S.p.A. and Italstrade S.p.A. v. The Hashemite Kingdom of Jordan, supra note 84; (3) Tradex Hellas S.A. v. Republic of Albania, ICSID Case No. ARB/94/2, Decision on Jurisdiction (Dec. 24,1996), available at http://www.italaw.com/sites/default/files/case-documents/ita0870.pdf (all last visited on Jan. 26, 2017).

96. Id. 
97 Qing Ren, Case Comment Ping An v Belgium, Temporal Jurisdiction of Successive BITs, 31 ICSID Rev. 133-7 (2016). See also Shengchang Wang \& Xiwen Peng, Learning from the Lose: Comment on the Ping An v. Belgium Investment Arbitration Case 从败诉中 汲取教训: 平安诉比利时投资仲裁案评析, Chinese Bar Association website, June 16, 2015, available at http://www.acla.org.cn/html/lvshiwushi/20150616/21458.html (last visited on Jan. 26, 2017).

98. Supra note 41, at 30. See also Ren, id. at 133.

99. Other remedies may be available to Ping An under the 1986 BIT or through Belgium's domestic courts.

100. Agreement between the Government of the Russian Federation and the Government of the People's Republic of China on the Promotion and Reciprocal Protection of Investments (2009), art. 11.1 and Agreement between the Government of the People's Republic of China and the Government of the Republic of Uzbekistan on the Promotion and Protection of Investments (2011), art. 14.1. The word 'arose' was used in the English versions of these two articles. In the Chinese versions, however, “引起” (arose) was used in Article 11.1 of the Agreement with Russian Federation and “发生” (happened) was used in Article 14.1 of the Agreement with Uzbekistan.

101. Supra note 41, at. 30.

102. Agreement on encouragement and reciprocal protection of investments between the Kingdom of the Netherlands and the Czech and Slovak Federal Republic (1992), art. 9.

103. NAFTA art. 1131.2.

104. Similar mechanisms can also be found in Article 34 of the European Union's proposal for the Transatlantic Trade and Investment Partnership (2015) and Article 30.3 of the US Model BIT of 2012.

105. Free Trade Agreement between the Government of Australia and the Government of the People's Republic of China (2015), art. 9.18.2.

106. The number here includes the Agreement between the Government of the United Kingdom of Great Britain and Northern Ireland and the Government of the People's Republic of China (1986). 